\title{
Cultivation of Algae Polyculture in Municipal Wastewater with $\mathrm{CO}_{2}$ Supply
}

\author{
Lara PODKUIKO ${ }^{*}$, Mari-Liis KASEMETS ${ }^{2}$, Timo KIKAS ${ }^{3}$, Inga LIPS ${ }^{4}$ \\ ${ }^{1,3}$ Estonian University of Life Sciences, F.R. Kreutzwaldi 1a, 51014 Tartu, Estonia \\ ${ }^{2,4}$ Tallinn University of Technology Department of Marine Systems, Akadeemia tee 15, 12618 Tallinn, \\ Estonia
}

\begin{abstract}
In the past decades microalgae have been viewed as a promising source of sustainable biomass, because the cultivation of microalgae does not require arable land. Because the main use of the biomass has been envisaged as feedstock for biofuel, research has been directed on increasing the (lipid) yield of monospecies. However, because the production of biofuel from such virgin biomass is not economically viable, the production of the biomass should be coupled with other processes. In addition, cultivating polycultures may yield more biomass, while ensuring a stable culture. In this research Chlorella spp., Arthrospira platensis and Raphidocelis subcapitata were grown as a polyculture in municipal wastewater in order to remove nutrients. The results indicate that using microalgal polycultures may help reduce nitrogen and phosphorus by the level reglemented by the EU Council Directive. This may help reduce water treatment costs with simultaneous biomass production.
\end{abstract}

Keywords - Functional diversity; microalgae consortium; mixed species; multispecies; nutrient removal; polyculture; wastewater treatment

\section{INTRODUCTION}

When the idea first took off, microalgae seemed perfect for biofuel production. Microalgae contain a fair amount of lipids (20-50\% dry cell weight (DCW), and up to $80 \%$ DCW for Botryococcus braunii) which could be transformed into biodiesel and other biofuels such as ethanol and biogas [1], [2]. Cultivating algae does not compete with food crops nor does it require arable land altogether, thus avoiding issues connected to land clearing to produce new cropland [3], [4]. However after several life-cycle assessment analyses (LCA's) [5]-[7] it is starting to look that biofuels are not as economically feasible as it was first expected, because of high fossil fuel input during cultivation (mineral fertiliser use, culture mixing/pumping, temperature maintenance etc.) and downstream processing as well as (fossil based) fertilizer requirement.

Research to enhance algal biofuel production has been thorough, and the enthusiasm has been slowly declining. In order to enhance feasibility, a lot of approaches have been developed and researched, including different cultivation strategies to manipulate cellular metabolism (e.g. nitrogen deprivation to increase lipid yield, different light-dark regimes etc.), various cultivation vessel designs [8]-[14] and using selective environments [15], [16]. Nevertheless, most of the designs (e.g. open raceway ponds, tubular reactors, flat-plate

\footnotetext{
* Corresponding author.

E-mail address: lara.podkuiko@gmail.com 
reactors etc.) face biofouling issues at some point in the cultivation as well as consuming a lot of fossil-fuel derived energy for mixing and illumination, resulting in negative net energy ratios [7]. The downstream processing (dewatering and drying of the biomass, lipid extraction, transesterification) is also expensive because of the dilute nature of the cultures and the small size of the cells [17]-[19].

To be economically feasible, algal biomass cultivation has to combine several purposes and outputs, with biofuel or biomass as feedstock for biofuel only as one end product. Microalgal biofuel has the potential to become competitive if its production is combined with some other process or product, such as municipal and industrial wastewater treatment and/or $\mathrm{CO}_{2}$ sequestration from flue gas or extraction of high value compounds such as carotenoids etc. [20]-[22].

Municipal wastewater may contain up to $85 \mathrm{mgN} \mathrm{L}^{-1}$ and $15 \mathrm{mgP} \mathrm{L}^{-1}$, different industrial wastewaters have a varying amount of nitrogen, with up to $\sim 2450 \mathrm{mgN} \mathrm{L}^{-1}$ and $\sim 325$ $\mathrm{mgP} \mathrm{L}{ }^{-1}$ in swine farm wastewater [23]. As high concentration of nitrogen and phosphorus in natural water systems lead to eutrophication, most countries have strict regulations for the acceptable amount in wastewater discharge, thus most of the nutrients must be removed prior to release into natural streams. As nitrogen and phosphorus are the major nutrients required for algal cultivation, wastewater could serve as a good cultivation medium, enabling to reduce costs of algae cultivation and wastewater treatment, as algae provide additional oxygen to the system. Interestingly, an idea of using rainwater as an algae cultivation substrate has been explored recently, as rainwater may contain a fair amount of nitrogen [24]. If harvested, it could be used for algae cultivation, compensating water lost to evaporation as well as treating the rainwater for further use in other applications (e.g. urban gardening etc.) [25]-[27]. Another greatly researched topic is the sequestration/mitigation of carbon dioxide from industrial flue gasses in order to lessen the emissions of the greenhouse gas into the atmosphere. Carbon dioxide serves as a carbon source for the algae and thus might help enhance mass-cultivation with the simultaneous offsetting the cultivation costs [17], [28][33].

Algal biomass production could be enhanced through biodiversity effects. Regardless of the cultivation method or bioreactor design, previous research has been focused on culturing algal monocultures, much like agricultural monocrops. However, it has been found that a more diverse system yields more biomass as well as being more stable in fluctuating conditions/environments [34].

The main objectives of the paper in hand was to compare the productivity of an algal polyculture with that of monocultures in untreated municipal wastewater. A mixture of $\mathrm{CO}_{2}$ and $\mathrm{N}_{2}$ was provided to some of the cultures to potentially enhance biomass production. Wastewater used for the experiments was unsanitized/not sterilized.

\section{Materials ANd Methods}

\subsection{Cultures}

Cultures of Chlorella sp, Raphidocelis subcapitata and Arthrospira platensis were obtained from National Institute of Chemical Physics and Biophysics of Estonia. Chlorella spp. and R. subcapitata were grown in sterile Bold's Basal Medium (BBM) and Arthrospira platensis was grown in sterile BG-11 medium [35]. The algae cultures were non-axenic. The algae were pre-cultivated in a climate chamber with a set temperature of $23{ }^{\circ} \mathrm{C}$ under fluorescent lamps with an irradiance of $200 \mu \mathrm{mol} \mathrm{m}{ }^{-2} \mathrm{~s}^{-1}$ and a light-dark cycle of 16:8 hours. 


\subsection{Experimental setup}

$300 \mathrm{~mL}$ conical flasks with rubber stoppers were used as bioreactors. Clean but nonsterilized silicone tubing was pushed through the stoppers to deliver gas and/or provide mixing and take samples. Algae were grown as a consortium (Chlorella spp. $+R$. subcapitata + A. platensis) and monocultures in triplicate. As a control for cell count measurements, the algae were grown in the synthetic medium they were pre-grown in: BBM for the green algae and BG-11 for A.platensis. Primarily (mechanically) treated Municipal wastewater from Paljassaare wastewater treatment plant in Tallinn, Estonia (with rounded values of $55 \mathrm{mgN} \mathrm{L}^{-1}$ and $5 \mathrm{mgP} \mathrm{L}^{-1}$ a) was used as a treatment medium to grow the consortium and the monocultures. An air pump and air stones were attached to the flasks to provide mixing. As a second test condition, algae grown in wastewater were supplied with a 20/80\% mix of $\mathrm{CO}_{2}$ and $\mathrm{N}_{2}$ gas with a flow rate of $0.1 \mathrm{~L} \mathrm{~min}^{-1}$. All of the flasks were placed in the climate chamber with the conditions described above. During the course of the experiment no new nutrients were added, i.e. the cultures were grown as a batch. The experiment lasted for 11 days.

\subsection{Measurements}

Cell counts were performed using flow cytometry (BD Accuri ${ }^{\mathrm{TM}}$ C6, BD Life Sciences). Prior to measurements, samples were fixed with paraformaldehyde ( $1 \mathrm{~mL}$ per $5 \mathrm{~mL}$ sample).

Cell count samples were collected every 72 hours. Flow cytometry data were analysed using appurtenant software.

Samples for phosphate and inorganic nitrogen analyses were collected every 36 to 72 hours and analysed using an automated nitrite-nitrate, orthophosphate and total-N and total-P analyser (Lachat QuikChem ${ }^{\circledR} 8500$ Series 2 ). Because of the relatively high $\mathrm{N}$ and $\mathrm{P}$ content and turbidity, which the analyser is sensitive toward, the samples were diluted and filtered using $0.2 \mu \mathrm{m}$ syringe filters prior to measuring. The analyser was set to measure only the nitrites and nitrates, thus the other species of nitrogen present in wastewater (ammonia, urea) were not measured. Calibrations with 400, 250, 100, 40 and $4 \mu \mathrm{g} \mathrm{L}^{-1}$ with nitrite, nitrate and phosphate standard solutions (Sigma-Aldich) and with distilled water were performed before and during measurements to ensure accuracy and correctness.

\subsection{Statistical analysis}

Data manipulation and visualisation and statistics were performed using $\mathrm{R}$ ( R Core Team (2020). R: A language and environment for statistical computing. R Foundation for Statistical Computing, Vienna, Austria. URL https://www.R-project.org/)

\section{Results}

The results of cell count are summarised in Fig. 1 and Fig. 2. The initial drop in the first $24 \mathrm{~h}$ is most probably caused by the lag phase set in after the dilution effect (placing cultures into new conditions). Algal growth curves are typically described by 5 phases: (1) lag or induction phase, (2) exponential phase with rapid growth, (3) linear phase, where the relative growth rate declines, (4) stationary phase with almost no growth and finally the (5) death phase, where the culture starts to decline.

\footnotetext{
${ }^{\text {a }}$ Mean value of sample used for experiment. Wastewater values may fluctuate from sample to sample.
} 


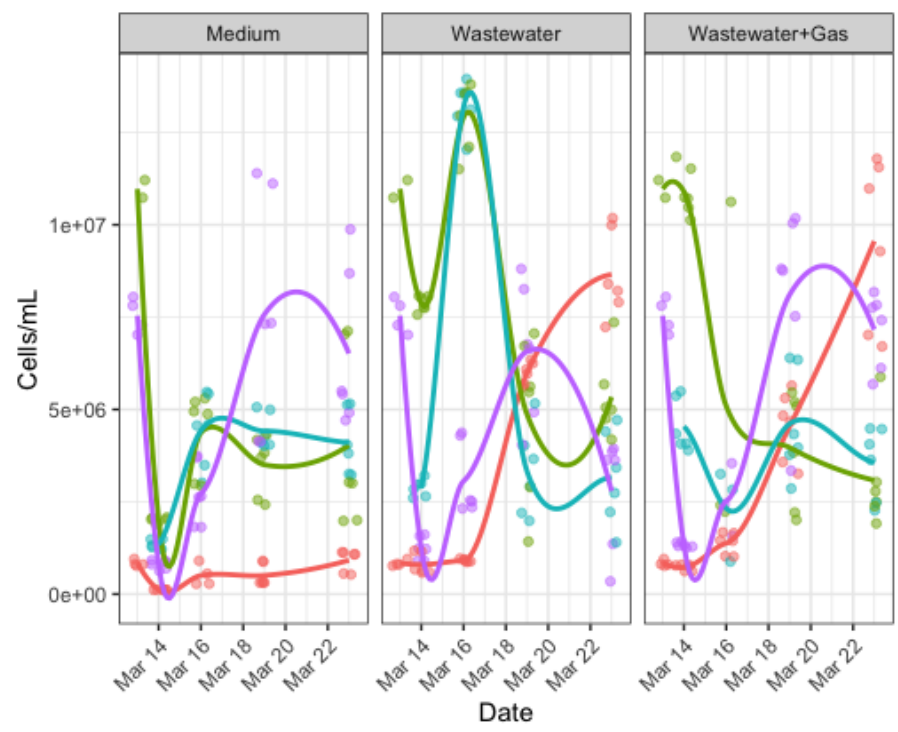

species

- Arthrospira platensis

$\simeq$ Chlorella sp

$\simeq$ Polyculture

- Raphidocelis subcapitata

a)

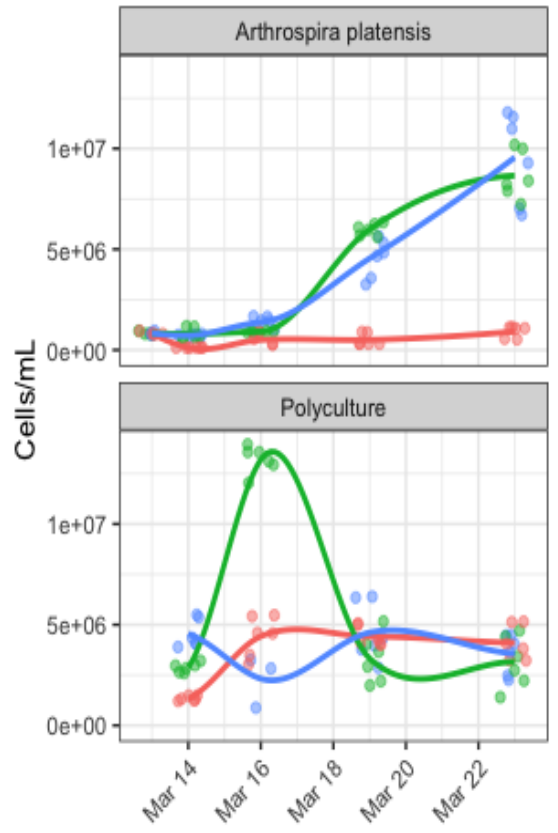

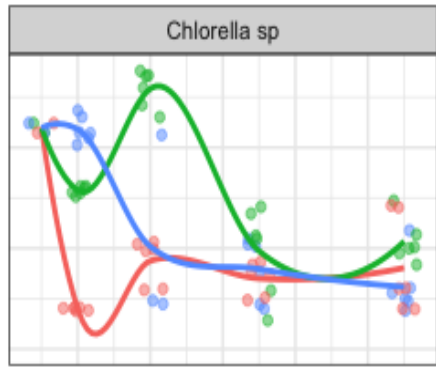

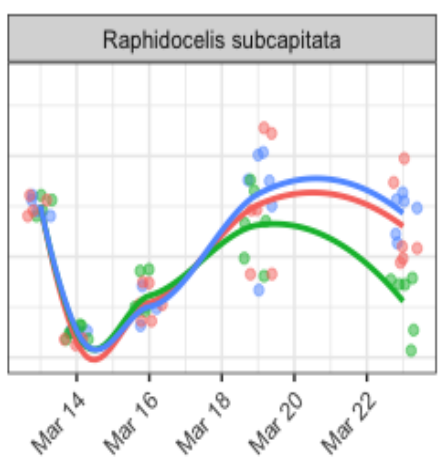

Date treatment

- Medium

- Wastewater

- Wastewater+Gas

b)

Fig. 1. Cell concentration grouped by: a) treatment, b) species.

From Fig. 1 it can be seen that the microalgae cultures grew well in the untreated wastewater. After the initial lag phase all cultures entered exponential growth except Chlorella spp. in the wastewater + gas treatment (Fig. 1b). The introduction of gas had a slight enhancing effect on $R$. subcapitata (which grew best in these conditions) and A. platensis, however, surprisingly, it did not enhance the growth of the polyculture and 
Chlorella spp. The cell count of Chlorella declined initially, but remained in stationary phase with just a slight decrease until the end of the experiment. It is difficult to tell from cell counts, whether the remaining cells were viable or not. This finding is contradictory with other similar studies [31], [34] and could be the result of some unexpected error in the experiment. However, from Table 1 it can be seen that the most phosphorus removal from the wastewater occurred in the Chlorella and polycultures with the addition of $\mathrm{CO}_{2}$, which could explain the lower cell counts - phosphorus was depleted quickly and cell division declined. In such conditions the cells could have started accumulating storage products such as lipids and starches.
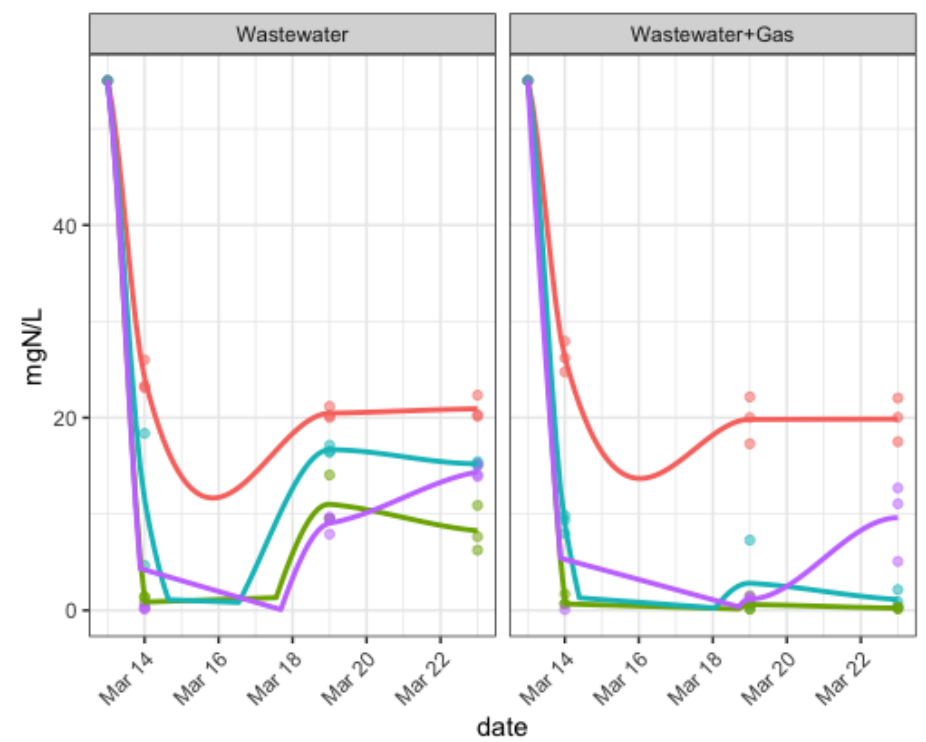

species

- Anthrospira platensis

- Chlorella spp

— Polyculture

- Raphidocelis subcapitata

a)
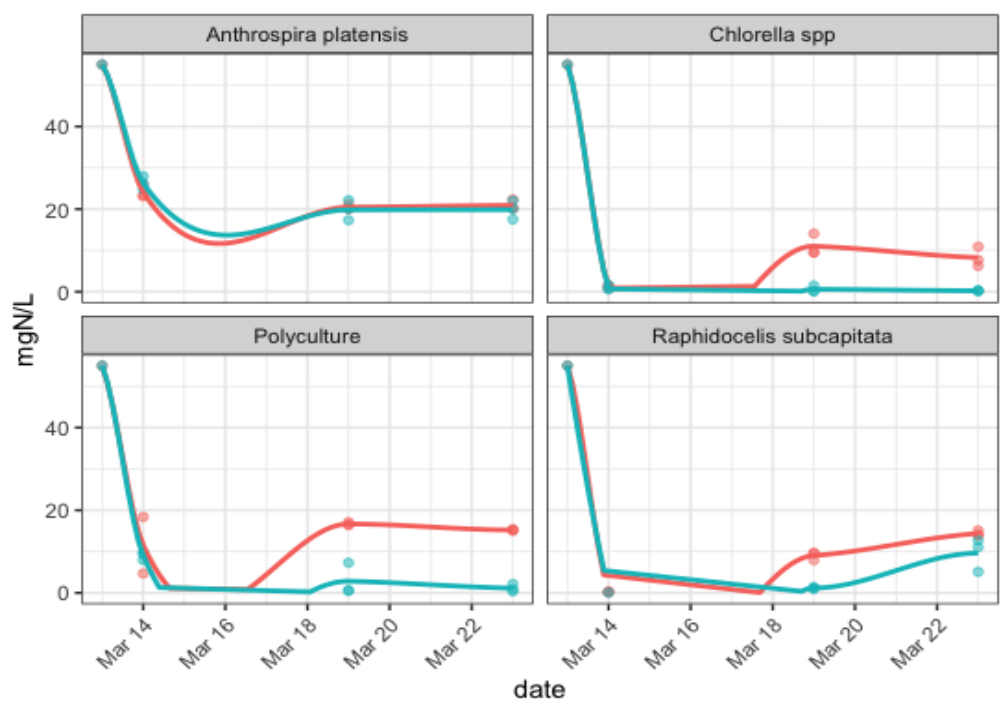

treatment

$\simeq$ Wastewater

- Wastewater+Gas

Fig. 2. Nitrogen consumption grouped by: a) treatment, b) species. 
$2020 / 24$

As the experiment was a batch cultivation, meaning no new nutrients were added to the cultures during the experiment, the decline of the cells is most probably caused by depletion of nutrients. This especially coincides in the case of Chlorella spp. and the polyculture. The slight rise of nitrogen in Fig. 2 could be the result of decaying organic matter, including algal cells. As the experimental cultures grew in unsanitied wastewater with bacteria and wild algae species present, some of the results of cell counts are also affected by the interactions between algae and the native inhabitants of the wastewater, which were not specifically researched in the scope of this paper.
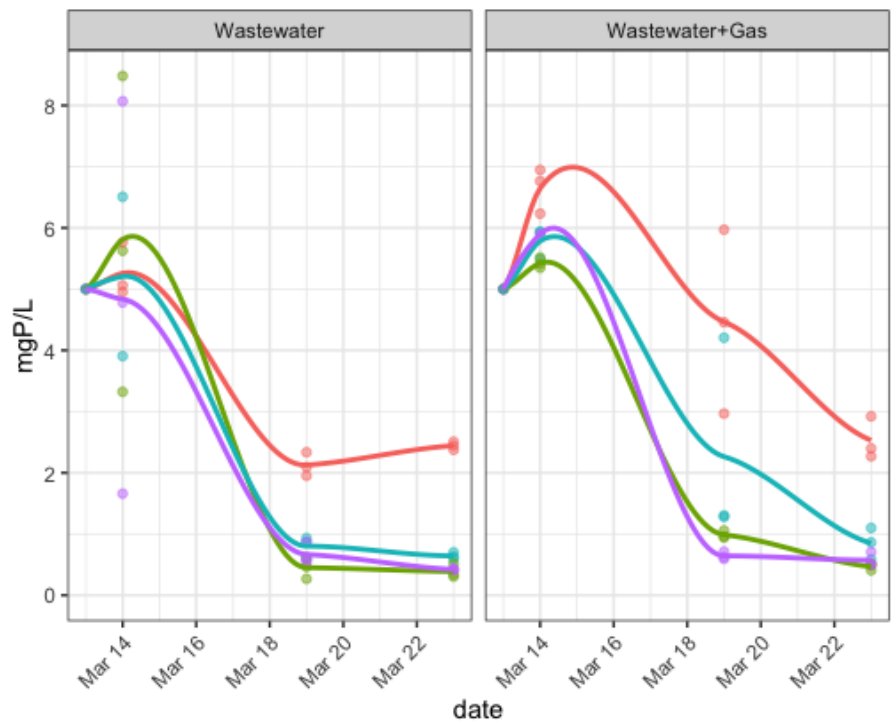

\section{species}

$\sim$ Anthrospira platensis

$\sim$ Chlorella spp

- Polyculture

- Raphidocelis subcapitata

a)
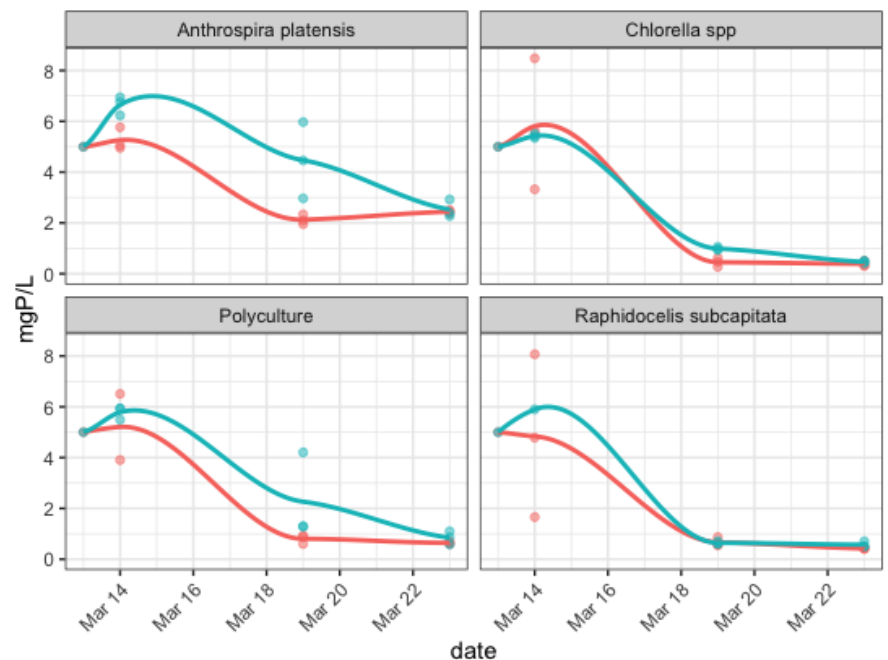

treatment

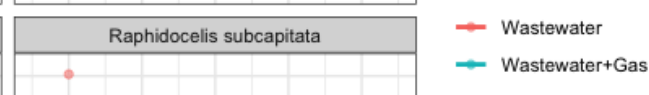

Fig. 3. Phosphorus consumption grouped by: a) treatment, b) species. 
Although the nitrogen and phosphorus (Fig. 3-6) was almost immediately depleted, the algae continued to grow. This could be done to two main reasons:

- Algae can grow for a period of time in nutrient deficient conditions. In the case of nitrogen starvation, algae often induce the production of lipids and high density carbohydrates. In the case of phosphorus deficiency, the algae may continue growth until the cells acquire a phosphorus debt of half of their usual content [2], [36].

- Only nitrites and nitrates were measured in this experiment, it is plausible that algae switched to using some other nitrogen form present in the wastewater (e.g. ammonia, urea). It has been shown that algae may uptake different species of nitrogen simultaneously, e.g. Chlorella may take up nitrate and ammonium at the same time [36].

In the European Union the allowed concentrations of nutrients (P-total and N-total) in urban wastewater discharge are regulated by the EU Council Directive 91/271/EEC of 21 May 1991 [37]. For the total nitrogen in treated wastewater is $15 \mathrm{mg} \mathrm{L}^{-1}$ for areas with 10000 100000 p.e. (population equivalent) and $10 \mathrm{mg} \mathrm{L}^{-1}$ for areas with $>100000$ p.e., the numbers for total phosphorus are $2 \mathrm{mg} \mathrm{L}^{-1}$ and $1 \mathrm{mg} \mathrm{L}^{-1}$, respectively (Table 1). According to the directive, the minimum percentage of reduction in relation to the load of the influent must be 70-80 for nitrogen and 80 for phosphorus.

TABLE 1. NUTRIENT REMOVAL BY ALGAL CULTURES

\begin{tabular}{|c|c|c|c|c|c|c|c|c|c|}
\hline \multicolumn{2}{|c|}{ Algae } & \multicolumn{2}{|c|}{$\begin{array}{c}\text { Initial } \\
\text { concentration, } \\
\mathrm{mg} \mathrm{L}^{-1}\end{array}$} & \multicolumn{2}{|c|}{$\begin{array}{c}\text { Final (lowest) } \\
\text { concentration*, } \mathrm{mg} \mathrm{L}^{-1}\end{array}$} & \multicolumn{2}{|c|}{ Removal, \% } & \multicolumn{2}{|c|}{ EU directive } \\
\hline Species & Treatment & $\begin{array}{c}\mathrm{NO}_{2}+ \\
\mathrm{NO}_{3}\end{array}$ & $\mathrm{PO}_{4}$ & $\begin{array}{c}\mathrm{NO}_{2}+ \\
\mathrm{NO}_{3}\end{array}$ & $\mathrm{PO}_{4}$ & $\begin{array}{c}\mathrm{NO}_{2}+ \\
\mathrm{NO}_{3}\end{array}$ & $\mathrm{PO}_{4}$ & $\begin{array}{l}\text { N-total, } \\
\mathrm{mg} \mathrm{L}^{-1}\end{array}$ & $\begin{array}{l}\text { P-total, } \\
\mathrm{mg} \mathrm{L}^{-1}\end{array}$ \\
\hline A. platensis & wastewater & \multirow{7}{*}{54.89} & \multirow{5}{*}{5.13} & $\begin{array}{c}20.9 \\
(20.471)\end{array}$ & $\begin{array}{c}2.44 \\
(2.13)\end{array}$ & 61.92 & 52.44 & \multirow{8}{*}{$10-15$} & \multirow{8}{*}{$1-2$} \\
\hline $\begin{array}{l}\text { Ar. } \\
\text { platensis }\end{array}$ & $\begin{array}{c}\text { wastewater }+ \\
\text { gas }\end{array}$ & & & $\begin{array}{c}19.9 \\
(19.8)\end{array}$ & $\begin{array}{c}2.53 \\
(2.53)\end{array}$ & 63.75 & 50.68 & & \\
\hline $\begin{array}{l}\text { Chlorella } \\
\text { spp. }\end{array}$ & wastewater & & & $\begin{array}{c}8.27 \\
(1.21)\end{array}$ & $\begin{array}{c}0.39 \\
(0.388)\end{array}$ & 84.93 & 92.4 & & \\
\hline $\begin{array}{l}\text { Chlorella } \\
\text { spp. }\end{array}$ & $\begin{array}{c}\text { wastewater }+ \\
\text { gas }\end{array}$ & & & $\begin{array}{c}0.24 \\
(0.236)\end{array}$ & $\begin{array}{c}0.47 \\
(0.467)\end{array}$ & 99.56 & 90.84 & & \\
\hline $\begin{array}{l}R . \\
\text { subcapitata }\end{array}$ & wastewater & & & $\begin{array}{c}14.4 \\
(0.238)\end{array}$ & $\begin{array}{c}0.42 \\
(0.420)\end{array}$ & 73.77 & 91.81 & & \\
\hline $\begin{array}{l}R . \\
\text { subcapitata }\end{array}$ & $\begin{array}{c}\text { wastewater }+ \\
\text { gas }\end{array}$ & & & $\begin{array}{c}9.62 \\
(0.086)\end{array}$ & $\begin{array}{c}0.57 \\
(0.573)\end{array}$ & 82.47 & 88.89 & & \\
\hline Polyculture & wastewater & & & $\begin{array}{c}15.2 \\
(11.5)\end{array}$ & $\begin{array}{c}0.64 \\
(0.644)\end{array}$ & 72.31 & 87.52 & & \\
\hline Polyculture & $\begin{array}{c}\text { wastewater }+ \\
\text { gas }\end{array}$ & & & $\begin{array}{c}1.13 \\
(1.13)\end{array}$ & $\begin{array}{c}0.85 \\
(0.849)\end{array}$ & 97.94 & 83.43 & & \\
\hline
\end{tabular}

*replicate means

From the results of the current experiment there seems that using algae cultures could be successfully used for nutrient removal from the untreated wastewater. All the values represented in bold meet the removal percentage criteria provided in the directive. As primarily treated wastewater was used, the use of algae could prove to be a good pre-treatment 
solution to offset the cost of water treatment, as biological nutrient removal is costly (more in Discussion). In summary, if the results of cell count and nutrient removal are combined, it could be said that polycultures had the best performance (rapid growth, high cell concentration and good nutrient removal).

\section{Discussion}

Within an ecosystem there are different niches according to available resources, which are occupied by different organisms adjusted to those niches. In an established ecosystem all the available niches are engaged and the resources distributed between organisms/species, thus making it difficult for an alien organism to enter and take root [38]-[40]. This is referred to as the competitive exclusion principle, where the organisms in direct competition for the same resources within a niche will either outcompete one another, forcing the weaker competitor out of the niche, or a specialisation toward a different resource will occur among the weaker competitor(s) [41].

In a monoculture cultivation, the single species does not use all the available resources (e.g. nutrient, light) leaving empty niches and thus opportunities for other species to invade, eventually leading to biofouling. Maintaining axenic or otherwise pure monocultures in especially challenging in large industrial facilities (such as mass-cultivations are) as well as labour-intensive and expensive, with the exception of cultures of extremophiles (halophiles, thermophilic and psychrophilic algae, acidophiles, e.g. Dunaliella spp, Cyanidiales (e.g. Cyanidioschyzon merolae), extremophilic cyanobacteria etc.) [42]-[46].

Additionally, productivity (i.e. biomass production) is linked to the biodiversity and especially functional diversity of an ecosystem (greater biodiversity has the potential to incorporate a higher functional group diversity). [34]. A system with higher biodiversity is also more stable with more stable biomass productions, because all niches are more likely to be occupied, the exchange of information and metabolites also adds to stability [22], [47]. Monocultures on the other hand are less tolerant to sudden changes in their environments and are more susceptible to epidemics caused by microbial pathogens and other specialised pathogens such as fungi, viruses and other protists [23], [48], [49]. Higher (functional) diversity and efficient nutrient uptake through niche engagement would heighten biomass assimilation and therefore nutrient uptake/removal, which is especially important in biological wastewater treatment. Additionally, using multiple species and organisms is beneficial in case of loss of one microorganism, which can be compensated by another organism belonging to the consortium [50]. Consequently, research into designing synthetic ecosystems for wastewater treatment and other biotechnological approaches has gained a fair amount of interest lately [16], [51], [52]. Algae have been shown to have complex interactions with different organisms inhabiting the wastewater - bacteria, protists, fungi and viruses, and some of the interactions may prove to have potentially important applications [47]. Therefore, in designing such synthetic ecosystems or co-cultures, it is essential to explore, understand and promote the interactions between algal species, which constitute the consortium, and algae-bacteria (and other) interactions.

Algae-algae interactions. Assemblages of algae can be complementary and utilize limited resources more efficiently in nutrient-limited environments. Higher complementarity yields more biomass and is influenced by the initial richness of the species pool [34], [41]. Low complementarity may result in competitive interactions in the co-cultivation of algae, where allelochemicals may be excreted to inhibit the competitive species. This most often occurs in unfavourable conditions (limited resources, low light, high $\mathrm{pH}$ ) and therefore the competitors 
may co-exist in abundant environments. On the other hand, the excretion of allelochemicals may provide resistance to pollutants and grazers, which can prove to also benefit the competitor species [50].

Algae-bacteria interactions. In nature, algae and bacteria interactions shape aquatic communities and biogeochemical cycles. The same kinds of interactions (nutrients and metabolites exchange, signal transduction etc.) are also present in wastewater. One of the most important interactions is perhaps the exchange of $\mathrm{CO}_{2}$ and $\mathrm{O}_{2}$. Oxygen supply to bacterial oxidation ponds demands high amounts of energy, which could be offset by photosynthetic oxygenation provided by microalgae. $\mathrm{CO}_{2}$ discharge resulting from the disintegration of organic matter by heterotrophic bacteria in return supply algae with carbon for biomass assimilation [53]. Most microalgae species also depend on bacteria for vitamin B12 supply as they cannot produce cobalamin themselves [47]. In return, microalgae can serve as a habitat for bacteria, protecting them from adverse environmental conditions and supplying them with extracellular polymers that can promote the growth of friendly bacteria [50]. Based on these interactions and other ecological principles the concept of synthetic ecology (as opposed to synthetic biology) has been proposed [41], [52]. Applying this concept may in the context of wastewater treatment with simultaneous biomass production may unlock new perspectives for sustainable bioeconomy.

Based on these concepts, three species of algae were used for the experiment (Fig. 4):

- Chlorella spp. is a small $(2-10 \mu \mathrm{m})$ spherical green algae with a large surface to volume ratio (SVR). A large SVR allows a more rapid absorption of nutrients compared to a smaller SVR. Chlorella has been grown in and is tolerant to wastewater [19], [23], [54].

- Raphidocelis subcapitata is a green alga with a sickle shape $(2-3 \times 8-14 \mu \mathrm{m})$ and a smaller SVR than Chlorella cells. R. subcapitata is sensitive to toxic compounds and is often used alongside planktonic crustacean Daphnia magna in ecotoxicological studies [55]-[58].

- Arthrospira (Spirulina) platensis is a cyanobacteria that absorbs a different light spectrum than green algae (phycobilisomes utilize the green-orange as opposed to red and blue spectrums absorbed by the chlorophylls of green algae) [59]. Cyanobacteria in general and A. platensis have also been cultivated in wastewater [60]-[63].

Although the number of species is not high enough to incorporate the effect of functional diversity, the results nevertheless illustrate the superiority of using polycultures instead of monocultures for algae cultivation and nutrient removal. The better combined performance of polycultures and the better growth of algae in wastewater as opposed to the medium may be due to the following:

1. Wastewater has a higher biodiversity compared to a medium. Although the medium used in the experiment was non-axenic, wastewater has a larger array of different organisms and the interactions between algae and bacteria can promote growth through mutual metabolites and gas exchange.

2. Wastewater as a more heterogeneous environment provides more niches for different organisms. Microalgae species have shown to have different affinities to different nitrogen forms (nitrate, nitrite, ammonia, urea), which are present in wastewater [49]. Thus, in case of depletion of one form of nutrient it is possible to shift to using another form present. 


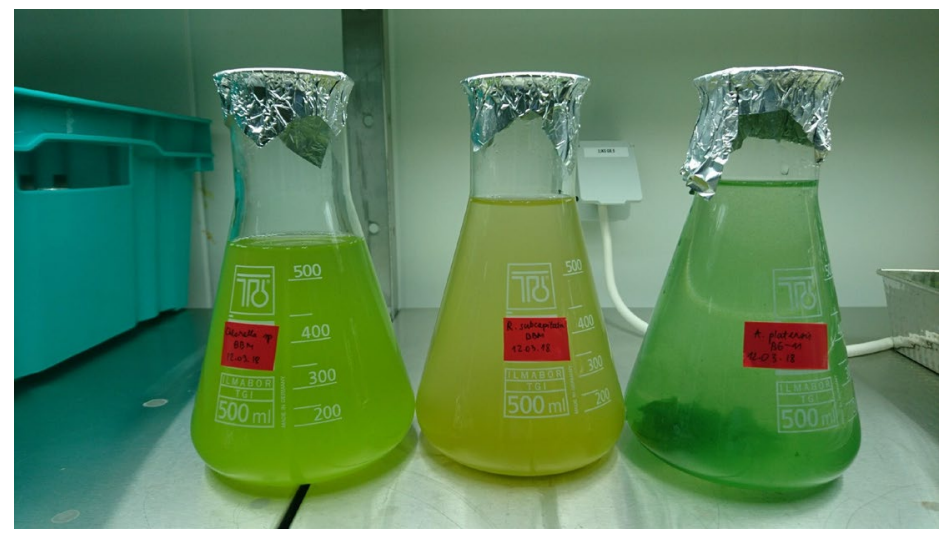

Figure 4. Example of algae species used in the experiment (personal collection). From the left: Chlorella sp, R. subcapitata, A. platensis.

The wastewater used in the experiment was unsanitized in order to allow the algae-bacteria (and other organisms such as fungi, protists, viruses in the wastewater) interactions to materialize. Additionally, it would not be rational or rather impossible to sterilise the wastewater in a large-scale setup, as it would prove unnecessarily costly and thus unsustainable in the long run. The system should be as robust as possible in order to be stable and cost-effective [50], [64].

\section{Conclusions}

Although not fully explored, the assemblages of microalgae may prove to have important applications in biotechnology, especially wastewater treatment. If properly designed, the interactions between co-cultured algae and wastewater bacteria may constitute a robust water treatment system with simultaneous nutrient removal and biomass accumulation, which could be further processed into biofuels or fertiliser, offsetting the cost of water-treatment and possibly creating a sustainable circular bioeconomy. The current study did not explore the possible algal interactions with bacteria from the biological treatment ponds, however it is an interesting and prospective topic for further research.

\section{ACKNOWLEDGEMENT}

The authors thank microbiologist Kai Künnis-Beres for her valuable insights and advice, Elise Joonas for the help with algal cultures and Riina Klais for help and inspiration.

\section{REFERENCES}

[1] Chen H., Zhou D., Luo G., Zhang S., Chen J. Macroalgae for biofuels production: Progress and perspectives. Renewable and Sustainable Energy Reviews 2015:47:427-437. https://doi.org/10.1016/j.rser.2015.03.086

[2] Gupta S. K., Malik A., Bux F. Algal Biofuels: Recent Advances and Future Prospects. Springer, 2017. https://doi.org/10.1007/978-3-319-51010-1

[3] Righelato R., Spracklen D. V. Carbon mitigation by biofuels or by saving and restoring forests? Science 2007:317(5840):902. https://doi.org/10.1126/science.1141361

[4] Fargione J., Hill J., Tilman D., Polasky S., Hawthorne P. Land clearing and the biofuel carbon debt. Science 2008:319(5867):1235-1238. https://doi.org/10.1126/science.1152747 
[5] Lam M. K., Lee K. T., Mohamed A. R. Current status and challenges on microalgae-based carbon capture. International Journal of Greenhouse Gas Control 2012:10:456-469. https://doi.org/10.1016/j.ijggc.2012.07.010

[6] Sander K., Murthy G. S. Life cycle analysis of algae biodiesel. International Journal of Life Cycle Assessment 2010:15(7):704-714. https://doi.org/10.1007/s11367-010-0194-1

[7] Dasan Y. K., Lam M. K., Yusup S., Lim J. W., Lee K. T. Life cycle evaluation of microalgae biofuels production: Effect of cultivation system on energy, carbon emission and cost balance analysis. Science of the Total Environment 2019:688:112-128. https://doi.org/10.1016/j.scitotenv.2019.06.181.

[8] Álvarez-Díaz P. D., Ruiz J., Arbib Z., Barragán J., Garrido-Pérez M. C., Perales J. A. Freshwater microalgae selection for simultaneous wastewater nutrient removal and lipid production. Algal Research 2017:24:477-485. https://doi.org/10.1016/i.algal.2017.02.006

[9] Cuellar-Bermudez S. P., Garcia-Perez J. S., Rittmann B. E., Parra-Saldivar R. Photosynthetic bioenergy utilizing CO2: An approach on flue gases utilization for third generation biofuels. Journal of Cleaner Production 2015:98:53-65. https://doi.org/10.1016/j.jclepro.2014.03.034

[10] Slade R., Bauen A. Micro-algae cultivation for biofuels: Cost, energy balance, environmental impacts and future prospects. Biomass and Bioenergy 2013:53:29-38. https://doi.org/10.1016/j.biombioe.2012.12.019

[11] Pires J. C. M., Alvim-Ferraz M. C. M., Martins F. G., Simões M. Wastewater treatment to enhance the economic viability of microalgae culture. Environmental Science and Pollution Research 2013:20(8):5096-5105. https://doi.org/10.1007/s11356-013-1791-x

[12] Posten C. Design principles of photo-bioreactors for cultivation of microalgae. Eng. Life Sci. 2009:9(3):165-177. https://doi.org/10.1002/elsc.200900003

[13] Cheah W. Y., Show P. L., Chang J.-S., Ling T. C., Juan J. C. Biosequestration of atmospheric $\mathrm{CO}_{2}$ and flue gascontaining $\mathrm{CO}_{2}$ by microalgae. Bioresour. Technol. 2014:184:190-201. https://doi.org/10.1016/j.biortech.2014.11.026

[14] Chen C. Y., Yeh K. L., Aisyah R., Lee D. J., Chang J. S. Cultivation, photobioreactor design and harvesting of microalgae for biodiesel production: A critical review. Bioresour. Technol. 2011:102(1):71-81. https://doi.org/10.1016/j.biortech.2010.06.159

[15] Mooij P. R., Stouten G. R., van Loosdrecht M. C. M., Kleerebezem R. Ecology-based selective environments as solution to contamination in microalgal cultivation. Current Opinion in Biotechnology 2015:33:46-51. https://doi.org/10.1016/j.copbio.2014.11.001

[16] Smith V. H., Crews T. Applying ecological principles of crop cultivation in large-scale algal biomass production. Algal Research 2014:4:23-34. https://doi.org/10.1016/j.algal.2013.11.005

[17] Bhola V., Swalaha F., Ranjith Kumar R., Singh M., Bux F. Overview of the potential of microalgae for $\mathrm{CO}_{2}$ sequestration. International Journal Environmental Science and Technology 2014:11(7):2103-2118. https://doi.org/10.1007/s13762-013-0487-6

[18] Razzak S. A., Hossain M. M., Lucky R. A., Bassi A. S., de Lasa H. Integrated $\mathrm{CO}_{2}$ capture, wastewater treatment and biofuel production by microalgae culturing -A review. Renewable and Sustainable Energy Reviews 2013:27:622-653. https://doi.org/10.1016/j.rser.2013.05.063

[19] Cheah W. Y., Ling T. C., Show P. L., Juan J. C., Chang J.-S., Lee D.-J. Cultivation in wastewaters for energy: A microalgae platform. Applied Energy 2016:179:609-625. https://doi.org/10.1016/j.apenergy.2016.07.015

[20] Chew K. W. et al. Microalgae biorefinery: High value products perspectives. Bioresource Technology 2017:229:5362. https://doi.org/10.1016/j.biortech.2017.01.006

[21] Ruiz J. et al. Towards industrial products from microalgae. Energy \& Environmental Science 2016:9(10):3036-3043. https://doi.org/10.1039/C6EE01493C

[22] Olofsson M., Lindehoff E., Legrand C. Production stability and biomass quality in microalgal cultivation Contribution of community dynamics. Engineering in Life Science 2019:19(5):330-340. https://doi.org/10.1002/elsc.201900015

[23] Christenson L., Sims R. Production and harvesting of microalgae for wastewater treatment, biofuels, and bioproducts. Biotechnology Advances 2011:29(6):686-702. https://doi.org/10.1016/j.biotechadv.2011.05.015

[24] Liu R., Stanford R. L., Deng Y., Liu D., Liu Y., Yu S. L. The influence of extensive green roofs on rainwater runoff quality: a field-scale study in southwest China. Environmental Science and Pollution Research 2020:27:12932-12941. https://doi.org/10.1007/s11356-019-06151-5

[25] Xie B. et al. Blending high concentration of anaerobic digestion effluent and rainwater for cost-effective Chlorella vulgaris cultivation in the photobioreactor. Chemical Engineering Journal 2019:360:861-865. https://doi.org/10.1016/j.cej.2018.12.009.

[26] Nwoba E. G., Vadiveloo A., Ogbonna C. N., Ubi B. E., Ogbonna J. C., Moheimani N. R. Algal Cultivation for Treating Wastewater in African Developing Countries: A Review. Clean Soil, Air, Water 2020:48(3):2000052. https://doi.org/10.1016/j.biortech.2016.12.044

[27] Kang W., Chai H. Assessment of runoff treatment operations with combined rainwater treatment system in the old city zone. Water Supply 2019:19(8):2507-2516. https://doi.org/10.2166/wcc.2019.171 
[28] Ono E., Cuello J. L. Feasibility Assessment of Microalgal Carbon Dioxide Sequestration Technology with Photobioreactor and Solar Collector, Biosystem Engineering 2006:95(4):597-606. https://doi.org/10.1016/j.biosystemseng.2006.08.005

[29] de Morais M. G., Costa J. A. V. Biofixation of carbon dioxide by Spirulina sp. and Scenedesmus obliquus cultivated in a three-stage serial tubular photobioreactor. Journal of Biotechnology 2007:129(3):439-445. https://doi.org/10.1016/j.jbiotec.2007.01.009

[30] Lara-gil J. A., Álvarez M. M., Pacheco A. Toxicity of flue gas components from cement plants in microalgae $\mathrm{CO}_{2}$ mitigation system. Journal of Applied Phycology 2014:357-368. https://doi.org/10.1007/s10811-013-0136-y

[31] Sudhakar K., Suresh S., Premalatha M. An overview of $\mathrm{CO}_{2}$ mitigation using algae cultivation technology. International Journal of Chemical Research 2011:3(3):110-117. https://doi.org/10.9735/0975-3699.3.3.110-117

[32] Da Rosa A. P. C., Carvalho L. F., Goldbeck L., Costa J. A. V. Carbon dioxide fixation by microalgae cultivated in open bioreactors. Energy Conversion and Management 2011:52(8-9):3071-3073. https://doi.org/10.1016/j.enconman.2011.01.008

[33] Khozin-Goldberg A. S. I. High- $\mathrm{CO}_{2}$ tolerance in microalgae: possible mechanisms and implications for biotechnology and bioremediation. Biotechnology Letters 2013:1745-1752. https://doi.org/10.1007/s10529-013-1274-7

[34] Roelke D. L. Applying principles of resource competition theory to microalgae biomass production: A more refined relationship between species richness and productivity. Algal Research 2017:25:431-438 https://doi.org/10.1016/j.algal.2017.06.002

[35] Andersen R. A. Algal Culturing Techniques. Elsevier, Academic Press, 2005.

[36] Myers J. Physiology of the Algae. Annual Review of Microbiology 1951:5:157-180. https://doi.org/10.1146/annurev.mi.05.100151.001105

[37] Directive 91/271/EEC of the European Parliament and of the council concerning urban waste water treatment. Official Journal of the European Communities 1998:1881:1-5.

[38] Giller P. Community structure and the niche. Springer, Science \& Business Media, 2012.

[39] Cardinale B. J. Biodiversity improves water quality through niche partitioning. Nature 2011:472(7341):86-89. https://doi.org/10.1038/nature09904

[40] Litchman E., Edwards K. F., Klausmeier C. A., Thomas M. K. Phytoplankton niches, traits and eco-evolutionary responses to global environmental change. Marine Ecology Progress Series 2012:470:235-248 https://doi.org/10.3354/meps09912

[41] Kazamia E., Aldridge D. C., Smith A. G. Synthetic ecology - A way forward for sustainable algal biofuel production? Journal of Biotechnology 2012:162(1):163-169. https://doi.org/10.1016/j.jbiotec.2012.03.022

[42] Varshney P., Mikulic P., Vonshak A., Beardall J., Wangikar P. P. Extremophilic micro-algae and their potential contribution in biotechnology. Bioresource Technology 2015:184:363-372. https://doi.org/10.1016/j.biortech.2014.11.040

[43] Pick U. Dunaliella-A Model Extremophilic Alga. Israel Journal of Plant Science 1998:46(2):131-139. https://doi.org/10.1080/07929978.1998.10676720

[44] Foflonker F. et al. The unexpected extremophile: Tolerance to fluctuating salinity in the green alga Picochlorum. Algal Research 2016:16:465-472. https://doi.org/10.1016/j.algal.2016.04.003

[45] Ciniglia C., Yoon H. S. U., Pollio A., Pinto G., Bhattacharya D. Hidden biodiversity of the extremophilic Cyanidiales red algae. Molecular Ecology 2004:13(7):1827-1838. https://doi.org/10.1111/j.1365-294X.2004.02180.x

[46] Malavasi V., Soru S., Cao G. Extremophile Microalgae: the potential for biotechnological application. Journal of Phycology 2020:56(3):559-573. https://doi.org/10.1111/jpy.12965

[47] Santos C. A., Reis A. Microalgal symbiosis in biotechnology. Applied Microbiology and Biotechnology 2014:98(13):5839-5846. https://doi.org/10.1007/s00253-014-5764-x

[48] Shurin J. B. et al. Industrial-strength ecology: Trade-offs and opportunities in algal biofuel production. Ecol. Lett., 2013:16(11):1393-1404. https://doi.org/10.1111/ele.12176

[49] Mandal S., Shurin J. B., Efroymson R. A., Mathews T. J. Functional divergence in nitrogen uptake rates explains diversity-productivity relationship in microalgal communities. Ecosphere 2018:9(5):e0228, https://doi.org/10.1002/ecs2.2228

[50] Gonçalves A. L., Pires J. C. M., Simões M. A review on the use of microalgal consortia for wastewater treatment. Algal Research 2017:24:403-415. https://doi.org/10.1016/j.algal.2016.11.008

[51] Ryan Georgianna D., Mayfield S. P. Exploiting diversity and synthetic biology for the production of algal biofuels. Nature 2012:488(7411):329-335. https://doi.org/10.1038/nature11479

[52] Goers L., Freemont P., Polizzi K. M. Co-culture systems and technologies: Taking synthetic biology to the next level. Journal of the Royal Society Interface 2014:11(96). https://doi.org/10.1098/rsif.2014.0065

[53] Su Y., Mennerich A., Urban B. Municipal wastewater treatment and biomass accumulation with a wastewater-born and settleable algal-bacterial culture. Water Research 2011:45(11):3351-3358. https://doi.org/10.1016/j.watres.2011.03.046

[54] Wang L. et al. Cultivation of green algae Chlorella sp. in different wastewaters from municipal wastewater treatment plant. Applied Biochemistry and Biotechnology 2010:162(4):1174-1186. https://doi.org/10.1007/s12010-009-8866-7 
[55] Candido J. P., Andrade S. J., Fonseca A. L., Silva F. S., Silva M. R. A., Kondo M. M. Ibuprofen removal by heterogeneous photocatalysis and ecotoxicological evaluation of the treated solutions. Environmental Science and Pollution Research 2016:23(19):19911-19920. https://doi.org/10.1007/s11356-016-6947-z

[56] Nogueira P. F. M., Nakabayashi D., Zucolotto V. The effects of graphene oxide on green algae Raphidocelis subcapitata. Aquatic Toxicoloy 2015:166:29-35. https://doi.org/10.1016/j.aquatox.2015.07.001

[57] Nogueira V. et al. Assessing the ecotoxicity of metal nano-oxides with potential for wastewater treatment. Environ. Science and Pollution Research 2015:22(17):13212-13224. https://doi.org/10.1007/s11356-015-4581-9

[58] Santos J. I. et al. Environmental safety of cholinium-based ionic liquids: assessing structure-ecotoxicity relationships. Green Chem., 2015:17(9):4657-4668. https://doi.org/10.1039/C5GC01129A

[59] Simis S. G. H., Huot Y., Babin M., Seppälä J., Metsamaa L. Optimization of variable fluorescence measurements of phytoplankton communities with cyanobacteria. Photosynthesis Research 2012:112(1):13-30. https://doi.org/10.1007/s11120-012-9729-6

[60] Cheunbarn S., Peerapornpisal Y. Cultivation of Spirulina platensis using anaerobically swine wastewater treatment effluent. Int. J. Agric. Biol., 2010:12(4):586-590.

[61] Mezzomo N. et al. Cultivation of microalgae Spirulina platensis (Arthrospira platensis) from biological treatment of swine wastewater. Ciência e Tecnol. Aliment. 2010:30(1):173-178. https://doi.org/10.1590/S0101-20612010000100026

[62] Markou G., Chatzipavlidis I., Georgakakis D. Cultivation of Arthrospira (Spirulina) platensis in olive-oil mill wastewater treated with sodium hypochlorite. Bioresource Technology 2012:112:234-241. https://doi.org/10.1016/j.biortech.2012.02.098

[63] Martins J., Peixe L., Vasconcelos V. M. Unraveling Cyanobacteria Ecology in Wastewater Treatment Plants (WWTP). Microbial Ecology 2011:62(2):241-256. https://doi.org/10.1007/s00248-011-9806-y

[64] Nath A., Dixit K., Sundaram S. Developing Designer Microalgae Consortia: A Suitable Approach to Sustainable Wastewater Treatment. In Application of Microalgae in Wastewater Treatment: Volume 1: Domestic and Industrial Wastewater Treatment, S. K. Gupta and F. Bux, Eds. Cham: Springer International Publishing, 2019:57-80. https://doi.org/10.1007/978-3-030-13913-1_4 